\title{
The use of IT tools for the analysis and evaluation of psychomotor efficiency of employees
}

\author{
Joanna Sadłowska - Wrzesińska ${ }^{1}$, Izabela Gabryelewicz ${ }^{2}$, and Patryk Krupa ${ }^{2, *}$ \\ ${ }^{1}$ Poznan University of Technology, ul. Strzelecka 11, Poznań 60-965, Poland \\ ${ }^{2}$ University of Zielona Góra, ul. Szafrana 4, 65-516 Zielona Góra, Poland
}

\begin{abstract}
The paper presents a computer application ePiórkowski, which allows to carry out psychomotor efficiency tests using a computer. The software enables to measure the response time of mental skills such as: psychomotor response time, resistance to fatigue and stress, concentration and decision making time. The application is a precise mapping of standard measurement equipment called Piorkowski apparatus. The paper describes the rule of operation and the way of operating the application. It also includes a comparison of the application with the standard equipment and a presentation of additional functions, not offered by the traditional apparatus. What is more, the paper describes the construction, interface and technology used for the software development.
\end{abstract}

\section{Introduction}

An effective operation of a machine depends of its reliability as well activities of people who operate it. As a result, when analysing the work process, it is essential to consider not only the machine itself but also a man and the environment in which he/she together with the machine realises set goals. In accordance to the systems theory, a system composed of a man, a machine and an environment is called a sociotechnical system.

The following stages can be distinguished in the process of technical object exploitation:

- pre-use processes,

- machines use processes,

- process of providing ability,

- supply processes,

- machines liquidation processes,

- processes supporting operation.

A man, being a deciding party, plays a superior role in a sociotechnical system. A superior role of men is especially visible in case of operators of machines and devices. In situations when working cycles are related with numerous start-ups and stops, there occur changes of tasks, noise, toxic substances, limited visibility, necessity of observing signalling devices and prompt decision making. These states result in fast fatigue and limitations of the capabilities

\footnotetext{
* Corresponding author: pkrupa@uz.zgora.pl
} 
to properly operate machines. Thus, apart from knowledge and skills, the following factors are decisive in evaluating employee's usability for work:

1. Psychomotor performance:

- response pace,

- adequacy of responses,

- visual-motor coordination.

2. Intellectual fitness and cognitive processes:

- observing and caution,

- understanding of situations,

- anticipation.

3. Personality:

- social maturity,

- emotional maturity.

The importance of the human factor is reflected in the Guide to application of the Machinery Directive 2006/42/EC, where, in accordance to norm EN ISO 6385:2004 Ergonomic principles in the design of work systems, ergonomics is defined as follows: „Ergonomics (or the study of human factors) is the scientific discipline concerned with the understanding of interactions among human and other elements of a system, and the profession that applies theory, principles, data and methods to design in order to optimize human well-being and overall system performance". Requirements concerning machines and devices are presented in Figure 1. Those requirements concern the human factor. That means, the adjustment of a work place to psychomotor capabilities of human [2, 3].
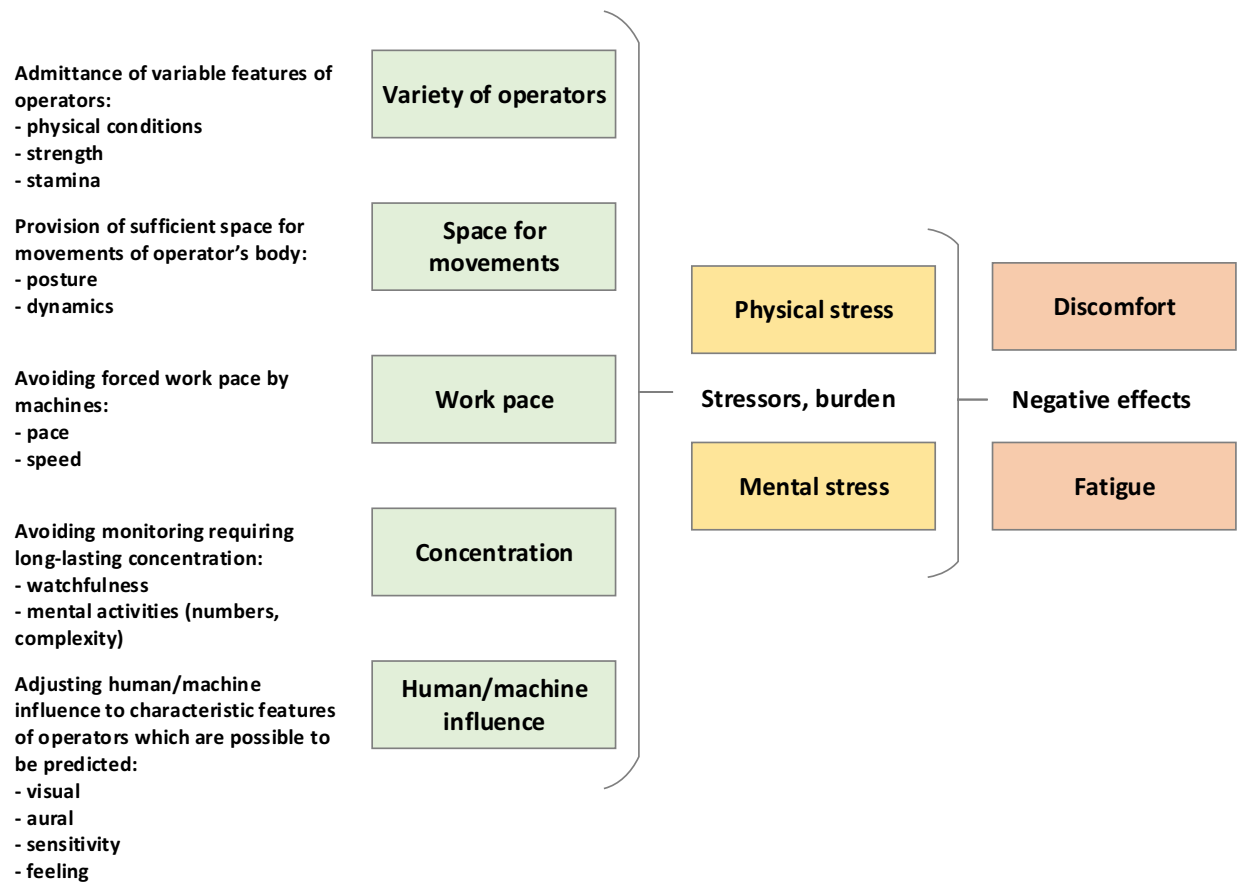

Fig. 1. Ergonomic requirements set for work places.

Source: Guide to application of the Machinery Directive 2006/42/EC, Rev. 2. June 2010, edited by Ian Freser, European Commission - Enterprise and Industry

However, it is not always possible to adjust a work place to psychomotor capabilities of human in an optimal way. Such lack of adjustment can result in professional illnesses of 
employees. That is why, employees' psychomotor capability is included in provisions of law. The importance of psychomotor capability in work performance is included in the Order of the Minister of Work and Social Policy of 28 May 1996 concerning types of work requiring particular psychomotor efficiency (Journal of Laws no 62, item 287). The list covers 36 types of work that require particular psychomotor efficiency. Also in the Order of the Minister of Health and Social Welfare of 30 May 1996 on carrying out of medical examinations of workers, scope of preventive health care and physician's notices issued in cases prescribed by the Labour Code, which provides six categories of noxious and arduous factors, that can occur at work places $[9,10]$. The fifth category includes Other factor, such as:

- Adverse psycho-social factors:

- Threats resulting from constant significant information inflow and readiness to respond;

- Threats resulting from working on a decisive and related with responsibility positions;

- Threats resulting from exposure to death;

- Threats resulting from work monotony;

- Works requiring full psychomotor efficiency;

- Works at heights;

- Working on forced position;

- Work requiring monotype movements of limbs;

- Work requiring constant and long-lasting effort of voice;

Machines and devices are mainly used for production and services. In the manufacturing process, human work must be considered as well. It constitutes the basic factor: launches and controls any manufacturing factors. The efficiency and productivity of machines depend on the fitness of a worker, his qualifications and work intensity. Natural traits and capabilities of workers are not uniform, but human can adjust to various work conditions.

According to studies, accidents and work disturbances occur when there is a disorder of motor, psychic or mental coordination, caused by various reasons. A lack of concentration causes e.g. a lack of stability of the whole system and often it is a threat to health and life of human, what is a direct cause of accidents, e.g. of drivers. Due to that, it is essential to eliminate fatigue, overworking, poor work conditions, excessive pace of work, and stress. Management over use of machines consists in giving and receiving orders and controlling as well as coordinating such process. Thus, psychomotor efficiency of workers should be regularly examined, what may have a deciding role in allowing one to perform particular work.

\section{Testing psychomotor efficiency of employees using ePiórkowski tool}

ePiórkowski tool allows conduction of psychological tests aimed at evaluation of visual and motor coordination using a linear arrangement of incentives. Testing psychomotor efficiency is addressed to examining employees working at positions requiring particular psychomotor efficiency. Figure 2 presents the traditional Piórkowski apparatus on the left and ePiórkowski application on the right. A participant under the test is to click the button which is currently highlighted. 


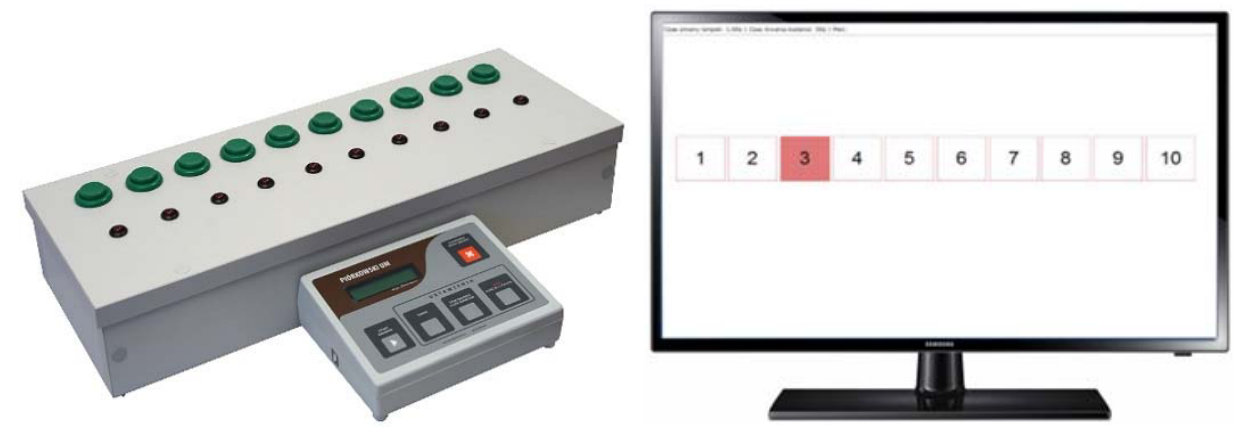

Fig. 2. Left - Piórkowski apparatus [1] in the traditional version; right - software version

Source: own elaboration on the basis of [1]

\section{ePiórkowski}

Application for testing psychomotor performance

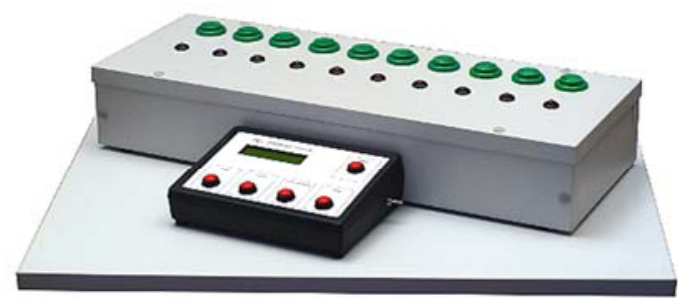

Opracovanie: Krupa Patryk (krupaputrykifremailicom)

\section{START TEST}

\begin{tabular}{|l|}
\hline Login \\
\hline Password \\
\hline \\
\hline
\end{tabular}

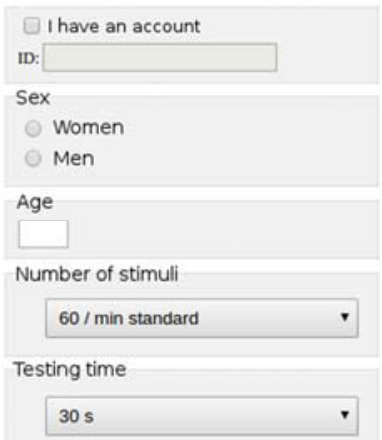

Parametr $\mathrm{A}$

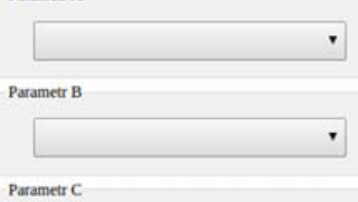

Fig 3. Interface - ePiórkowski [own elaboration]

The software was developed on the basis of the standard Piórkowski apparatus. It is intended to run the same amount of psychomotor efficiency examinations as in the case of the traditional device. The application is developed in order to enrich the testing device by additional functions, which the traditional instrument does not offer. The software version of the testing device is composed of several modules which can be later developed by further functions.

Currently, the software tool has the following inbuilt functions:

- database;

- analyser of results with variables: age, gender, date (exact date or a period), hour (exact hour or range of hours), pace, number of incentives, user ID, analysis ID, additional analysis parameter;

- possibility of users management (analysed persons) and administrators; 
- option of automatic generation of charts, including: normal and faulty reactions, obtained times, median of responses, particular response (in the case of selected analysis);

- option of analysis impression with additional parameters;

- adding comments to tests.

Features tested by apparatus / software [1]:

- time of psychomotor response in forced pace;

- visual-motor coordination;

- concentration;

- fitness in noticing elements displayed on the screen *;

- fitness in using pointing tools (computer mouse)*;

$*=$ Extended features (not available in the standard device).

The apparatus allows conducting tests in forced paces: $24^{*}, 30^{*}, 60,75,93,100^{*}, 107$, $120 *, 125,150$ incentives per minute and the testing time of: $30,60,90$, or $120 \mathrm{sec}$.

The apparatus calculates [1]:

- number of presented incentives,

- number of proper responses,

- number of incorrect responses * (including incorrect clicks *, omitted incentives*),

- average response time for all incentives*,

- average response time for only correct incentives*,

- longest time of waiting for response*,

- shortest time of waiting for response*,

* = Extended features (not available in the standard device).

\section{Application construction}

In order to work properly, the application requires:

- PC with any operating system;

- HTTP server;

- MySQL database server;

- PHP interpreter;

- pointing tool, e.g. computer mouse (if tests are conducted in such form);

- touch screen (recommended for tests by the author).

Figure 4 present the general scheme of the software operation. The application construction is based on interrelated files, including PHP, JavaScript programming languages and HTML markup language. The application design is developed using CSS - cascade style sheets. Files are divided in accordance to their role in the software (each block in the scheme is a separate file).

The application operation way is presented using block diagrams in Figure 4, which illustrates possibilities of moving around the program. 


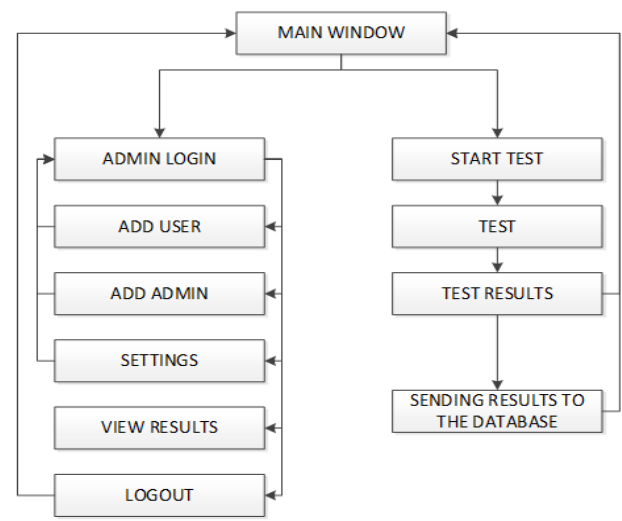

Fig. 4. Scheme of the application functioning [own elaboration]

Figure 5 presents variants of conducting tests. As you can see, the test can be conducted in numerous ways, depending on requirements:

- user has no account - anonymous test; tested person does not provide any personal data (mode used for appointing tested persons with the apparatus);

- used has no account - testing with basic information about tested person (age, gender);

- user has an account, name and ID number - we know his/her age and gender (an account must be created by an administrator);

There are also allowed additional combinations with three optional parameters A, B, C, which can be combined by selecting any configuration, e.g. parameters $\mathrm{A}+\mathrm{B}, \mathrm{A}+\mathrm{C}$ or $\mathrm{A}+\mathrm{B}+\mathrm{C}$. Parameters are generated by the administrator, who can input additional information about the test. The administrator can include places and conditions of conducting tests or factors influencing tested persons, e.g. assembly room, noise of over $85 \mathrm{~dB}$, lighting below 500 luxes. Green arrows indicate data which can be input but they are not required. The test can be initiated even if these options are not selected.

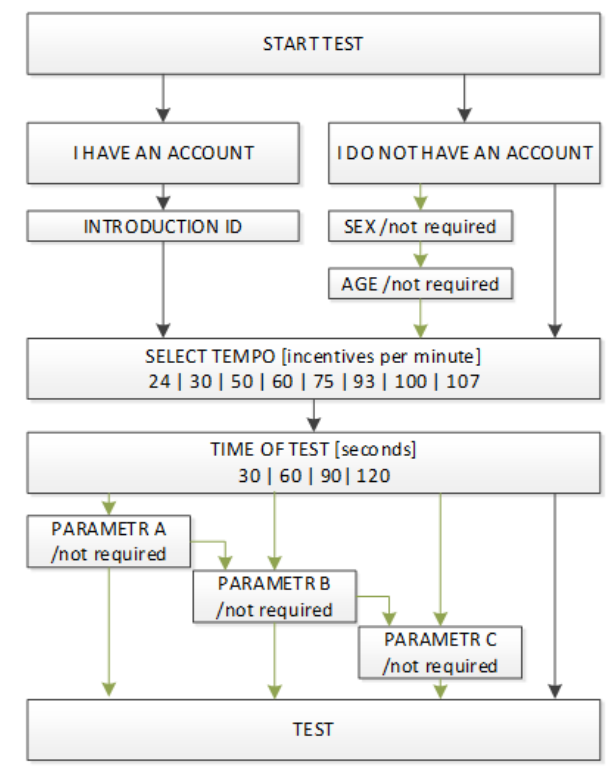

Fig. 5. Scheme of test start [own elaboration] 


\section{Program interface - Test}

Figure 6 presents the test window of ePiórkowski application. Similarly as in the classical apparatus, there are presented ten buttons, only one of which sends stimuli in proper time intervals. After the completed test, the user is directed to the results page (Figure 7).

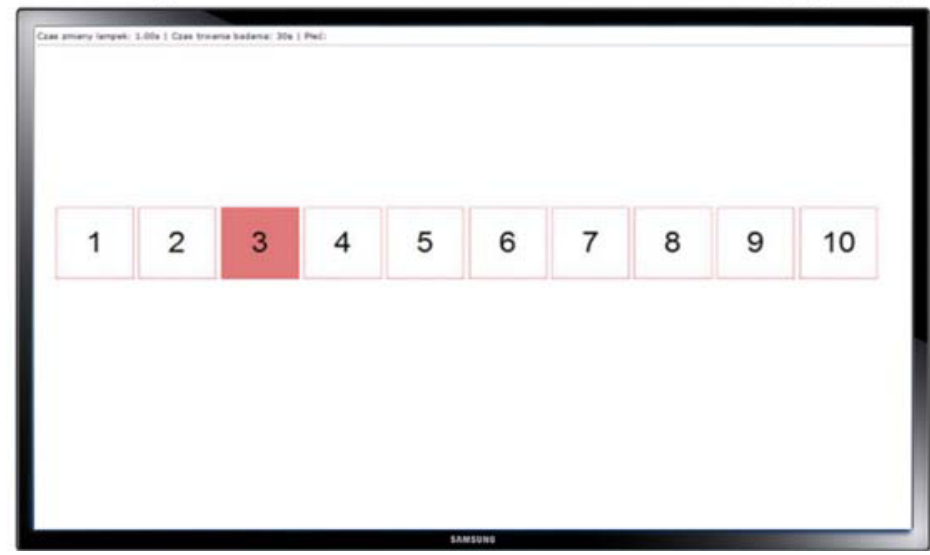

Fig. 6. Interface - test [own elaboration]

The test summary is displayed automatically immediately after its completion. The window of the final result is presented in Figure 7 and it includes results of particular responses and their summaries. Results are divided into three categories:

- 1 (green background) - normal response,

- 0 (red background) - invalid response (clicking a wrong button),

- CM (red background) - invalid response (lack of any response);

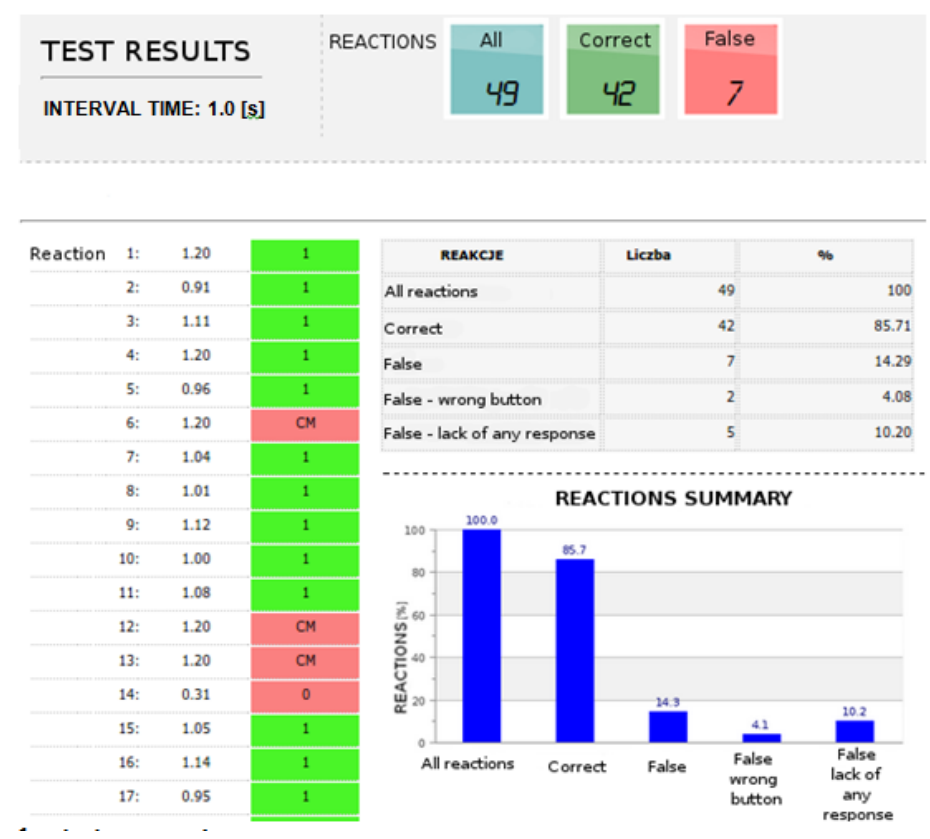

Fig. 7. Interface - test results [own elaboration] 


\section{Program interface - Administration panel}

Persons allowed to log in to the application are those having own login and password. Such persons have an access to the administration panel, which includes:

- test results analyser,

- all test results,

- users and administrators management,

- management of test additional parameters (each admin can add parameters according to own needs).

What is more, the panel allows addition and removal of users and administrators (Figure 8). The access to the panel is password protected in order to keep database safe from an access unauthorised persons. The analysed results are presented in the form of tables and dynamically generated charts. After a selection of tests in accordance to selected parameter, acquired information can be easily copied to word processors or other applications.

\section{ADMIN PANEL}

HELLO, ADMIN!

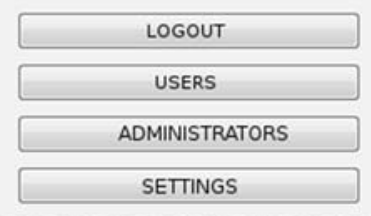

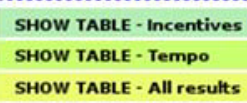

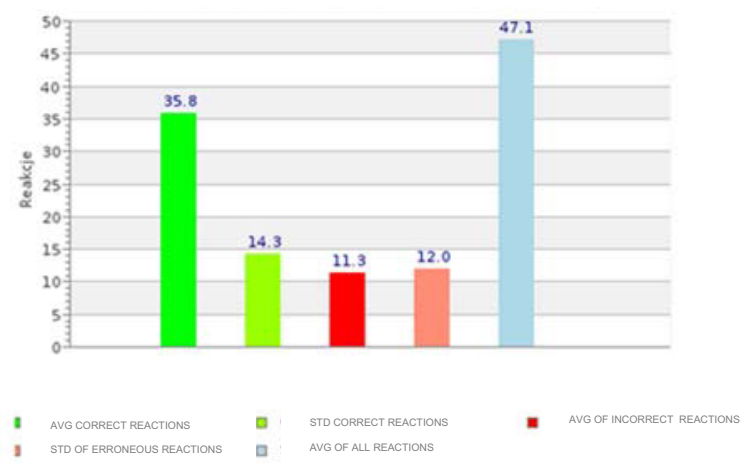

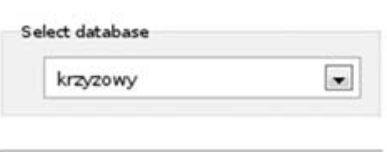

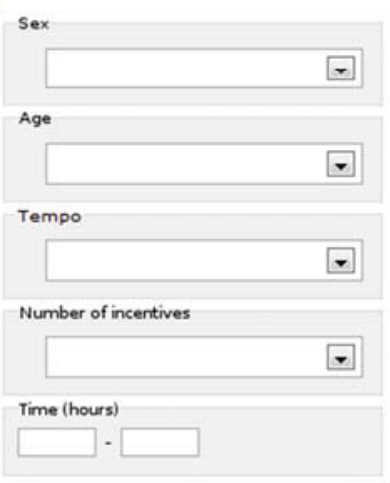

Fig. 8. Interface - administration panel [own elaboration]

\section{Used tools and technologies}

This part of the work presents all tools and technologies thanks to which this application for testing and analysing psychomotor function was developed. The following generally available free software was used for the application development

- Linux Mint - operating system,

- Apache - www server (application available for MS Windows and Linux),

- Bluefish - editor of HTML, PHP, CSS, SQL codes

- MySQL - database.

The application was developed using various programming languages, including: 
- HTML,

- PHP,

- JavaScript,

- SQL,

- CSS.

Thanks to the above mentioned tools and technologies, one can state that it is possible to develop a full value software using solely non-profit technological solutions and applications $[5,6,8]$.

The application utilises technologies, which enable the conduction of tests using numerous computers simultaneously. It is possible thanks to a local network and server applications.

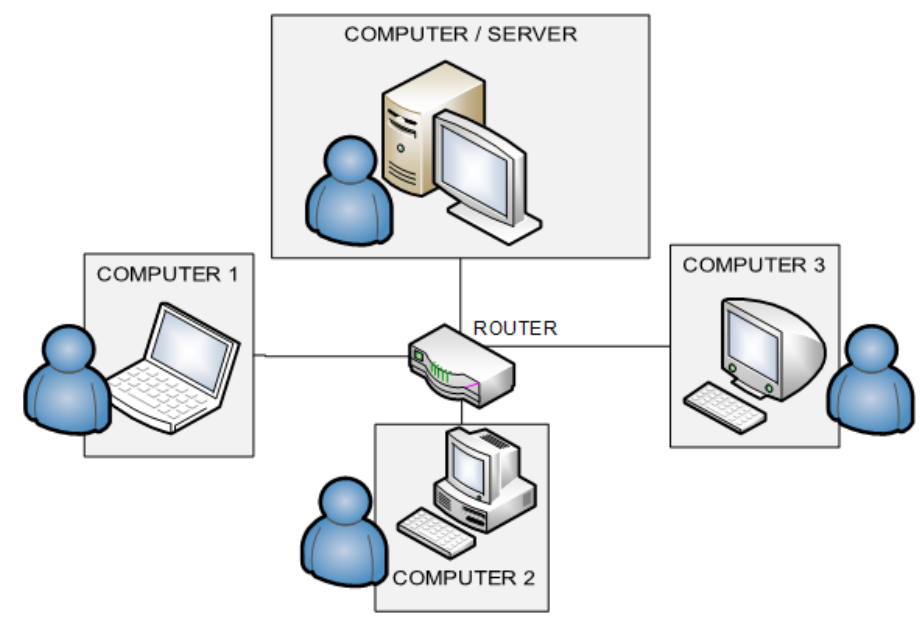

Fig. 9. Diagram - Network use of the application [own elaboration]

In order to conduct network tests, several computers are required. These devices do not need to be of the same type (PC, laptop, tablet, Mac), as well as not the same operating systems (Windows, Linux, MacOS). It is just enough that computers handled operation of local networks and had web browsers installed (Figure 9).

\section{Conclusions}

Tests of people working as operators of operating panels of multi-functional and multi-task technological devices and at monitoring (works requiring full fitness - control desks, signalling devices, control centres), should take the work position character into consideration. This means that tests should not be conducted using conventional devices but computer software. That can fully allow identify not only response time, stress-resistance, concentration, fatigue, but also worker's adaptation to work with computer screens (including touch screens).

Research results can be significantly influenced by past experience in working on computers (also with computer games). In numerous cases, the author experienced a negative approach to computer tests exhibited by elder people. On the other hand, young persons had a positive attitude to computer assisted studies and regarded them as play [7]. The main aim of the work was to develop an application, enabling testing of psychomotor efficiency. The developed application perfectly represents the operation method of the traditional instrument. What is more, the application is equipped in additional, very helpful tools for analysing the test results. The concept assumed the possibility of further development of programs. 
Computer assisted analyses have an advantage of technical possibilities and a further development options. In further directions of studies, one can conduct tests using computer apparatuses, which will be related with the influence of e.g. [7]:

- colour of displayed incentives,

- size (of displayed picture),

- shape of incentives.

\section{References}

1. Alfa Electronics - nowoczesne aparaty do badań psychologicznych (Alfa Electronics modern equipment for psychological research), http:/www.alfaelectronics.eu/index.php/aparat-piorkowski (2016)

2. EN ISO 6385:2004, Zasady ergonomiczne w projektowaniu systemów pracy (Ergonomic principles in the design of work systems) (2004)

3. I. Fraser, Guide to application of the Machinery Directive 2006/42/EC, 2nd Edition (2010)

4. I. Gabryelewicz, P. Krupa, J. Sadłowska-Wrzesińska, Koncepcja aplikacji wspomagającej ocenę poziomu kultury bezpieczeństwa w przedsiębiorstwie. Część 1 . Zastosowane narzędzia i technologie, Logistyka, 5 (Concept of application assisting the assessment of the level of the culture of the safety in the enterprise. Part 1. Applied tools and technologies, Logistics, 5) (2015)

5. L. Welling, L. Thomso, PHP and MySQL Web Development, Second Edition, (2003)

6. HTML \& Web Design Tips \& Techniques (McGraw-Hill, 2002)

7. P. Krupa, E. Kowal, G. Dudarski, Ocena sprawności psychomotorycznej z wykorzystaniem aplikacji komputerowej Zeszyty Naukowe Politechniki Poznańskiej. Organizacja i Zarządzanie, 67, (Evaluation of the psychomotor efficiency with using the computer application, Scientific booklets of the Poznań Technical University. The organization and Management, 67) (2015)

8. R. Sokół., ABC Linux (Helion, Gliwice, 2004)

9. Rozporządzenie Ministra Pracy i Polityki Socjalnej z dnia 28 maja 1996 r. w sprawie rodzajów prac wymagających szczególnej sprawności psychofizycznej (Dz. U. Nr 62, poz. 287); (Order of the Minister of Work and Social Policy of 28 May 1996 concerning types of work requiring particular psychomotor efficiency (Journal of Laws, 62, 287) (1996)

10. Rozporządzenie Ministra Zdrowia i Opieki Społecznej z dnia 30 maja 1996 r. w sprawie przeprowadzania badań lekarskich pracowników, zakresu profilaktyki opieki zdrowotnej nad pracownikami oraz orzeczeń lekarskich wydawanych do celów przewidzianych w Kodeksie pracy (Regulation of the Health Minister and the Social Welfare of 30 May 1996 conducting medical check-ups of employees, scope of the prevention of the health care above employees and medical certificates issued at targets stipulated in the Labour Code) (2015)

11. U. Vazirani, C. Papadimitriou, S. Dasgupta, Algorytmy (Algorithms), (PWN, Warszawa 2012) 